Note

\title{
Synthesis of Stable Isotope-Labeled Precursors for the Biosyntheses of Capsaicinoids, Capsinoids, and Capsiconinoids
}

\author{
Kenji Kobata, ${ }^{1,2}$ Makoto Mimura, ${ }^{1}$ Mai Sugawara, ${ }^{1}$ and Tatsuo Watanabe ${ }^{1, \dagger}$ \\ ${ }^{1}$ Graduate School of Nutritional and Environmental Sciences and Global COE Program, University of Shizuoka, \\ 52-1 Yada, Suruga-ku, Shizuoka 422-8526, Japan \\ ${ }^{2}$ Faculty of Pharmaceutical Sciences, Josai University, 1-1 Keyakidai, Sakado, Saitama 350-0295, Japan
}

Received March 10, 2011; Accepted May 10, 2011; Online Publication, August 7, 2011

[doi:10.1271/bbb.110187]

Stable isotope-labeled precursors were synthesized for an analysis by liquid chromatography-tandem mass spectrometry (LC-MS/MS) to elucidate the biosynthetic flow of capsaicinoids, capsinoids, and capsiconinoids. $\left[1^{\prime}-{ }^{13} \mathrm{C}\right]\left[5-{ }^{2} \mathrm{H}\right]-$ Vanillin was prepared by the condensation of guaiacol with $\left[{ }^{13} \mathrm{C}\right]$-chloroform and a $\mathrm{D}_{2} \mathrm{O}$ treatment. Labeled vanillylamine, vanillyl alcohol, ferulic acid, and coniferyl alcohol were prepared from the labeled vanillin. The labeled vanillylamine was converted to labeled capsaicinoid in a crude enzyme solution extracted from pungent Capsicum fruits.

Key words: stable isotope; capsaicinoid; capsinoid; capsaicin synthase; liquid chromatographytandem mass spectrometry (LC-MS/MS)

The substances responsible for the pungency of Capsicum peppers are a group of lipophilic alkaloids knows as capsaicinoid(s). The fundamental structure of capsaicinoids comprises a fatty acid amide of vanillylamine. Early studies in which classical in vivo tracer experiments were performed with radioactive precursors revealed the outline of the biosynthetic pathway for capsaicinoids (Fig. 1). ${ }^{1)}$ The aromatic moiety of capsaicinoids is derived from phenylalanine via the phenylpropanoid pathway. However, details of the downstream events on the pathway, i.e., the conversion of vanillin to vanillylamine, have not yet been elucidated. Recent molecular biological approaches suggest that the gene of a putative aminotransferase ( $p A M T)$ encodes an enzyme that catalyzes the conversion of vanillin to vanillylamine. $^{2)}$ A putative acyltransferase encoded in Pun1, namely capsaicin synthase (CS), is also considered a candidate enzyme that catalyzes the condensation of vanillylamine with a fatty acid to produce capsaicinoids. ${ }^{3)}$

Recent studies have revealed that many kinds of pungent and non-pungent Capsicum cultivars contained a novel group of non-pungent capsaicinoid-like substances named capsinoid(s). ${ }^{4}$ The fundamental structure of capsinoids comprises a fatty acid ester of vanillyl alcohol. We performed in our previous study an in vivo tracer experiment using radioactive precursors and found that the aromatic moiety of capsinoids, i.e., vanillyl alcohol, was derived from vanillin that was produced via the phenylpropanoid pathway (Fig. 1). ${ }^{5)}$ Although the factor for the conversion of vanillin to vanillyl alcohol seems to be crucial for capsinoid biosynthesis, it has not yet been elucidated. It is also not clear whether CS participates in the condensation of the vanillyl alcohol with a fatty acid in the final stage of capsinoid biosynthesis. A new class of coniferyl esters, namely capsiconinoids, has recently been found in several cultivars of pepper. ${ }^{6)}$ One of the possible biosynthetic precursors of capsiconinoids is coniferyl alcohol from the viewpoint of its chemical structure.

Clarifying details about the flow of metabolites is a relatively direct approach to elucidating the biosynthetic pathway, although a molecular biological approach would also be helpful in understanding the pathway. We chemically prepared stable isotopes of the putative precursors of capsaicinoids, capsinoids, and capsiconinoids in the present study as analytical tools to elucidate details of their biosynthesis (Fig. 2). The natural abundance of the $[\mathrm{M}+2]$ molecule to $[\mathrm{M}]$ molecule of these compounds is about $1 \%$, although that of $[\mathrm{M}+1]$ to $[\mathrm{M}]$ is about $9 \%$. We therefore synthesized doubly labeled compounds to get higher sensitivity, and then detected the enzyme activity of CS by liquid chromatography-tandem mass spectrometry (LC-MS/ MS), using the labeled precursor.

$\left[1^{\prime}-{ }^{13} \mathrm{C}\right]$-Vanillin was prepared according to the method of Ohara and Fukuda ${ }^{7)}$ with a slight modification. Briefly, a mixture of $4 \mathrm{~mL}$ of $5 \mathrm{M}$ guaiacol $(20 \mathrm{mmol})$ in $\mathrm{MeOH}, 390 \mu \mathrm{L}$ of $\left[{ }^{13} \mathrm{C}\right]$-chloroform $(4.9 \mathrm{mmol}$; Taiyo Nippon Sanso Co., Tokyo, Japan), and $11 \mathrm{~mL}$ of $2.8 \mathrm{M}$ $\mathrm{NaOH} a q$. was heated at $65^{\circ} \mathrm{C}$ for $24 \mathrm{~h}$. An ethyl acetate extract from the reaction mixture was purified by silica gel and subsequently by successive octadecylsilyl silica gel column chromatography to afford $111.9 \mathrm{mg}$ of [ $1^{\prime}$ $\left.{ }^{13} \mathrm{C}\right]$-vanillin $\left(0.73 \mathrm{mmol}, 15 \%\right.$ yield from $\left[{ }^{13} \mathrm{C}\right]$-chloroform). The ${ }^{13} \mathrm{C}$-nuclear magnetic resonance (NMR) spectrum $^{8)}$ of the compound showed an extremely intense signal at $191 \mathrm{ppm}$ indicating a carbonyl carbon containing the ${ }^{13} \mathrm{C}$ isotope. The ${ }^{1} \mathrm{H}-\mathrm{NMR}$ spectrum ${ }^{8)}$ showed a set of doublet signals coupled with $173 \mathrm{~Hz}$ at $9.82 \mathrm{ppm}$, indicating the presence of an aldehyde proton attached to the ${ }^{13} \mathrm{C}$ carbonyl carbon. The other signals in both NMR spectra of the compound were completely coincident with those of standard vanillin. The positive

$\dagger$ To whom correspondence should be addressed. Fax: +81-54-264-5550; E-mail: watanbt@u-shizuoka-ken.ac.jp

Abbreviations: APCI-MS, atmospheric pressure chemical ionization-mass spectrometry; CS, capsaicin synthase; LC-MS/MS, liquid chromatography-tandem mass spectrometry; MRM, multiple reaction monitoring; NMR, nuclear magnetic resonance 


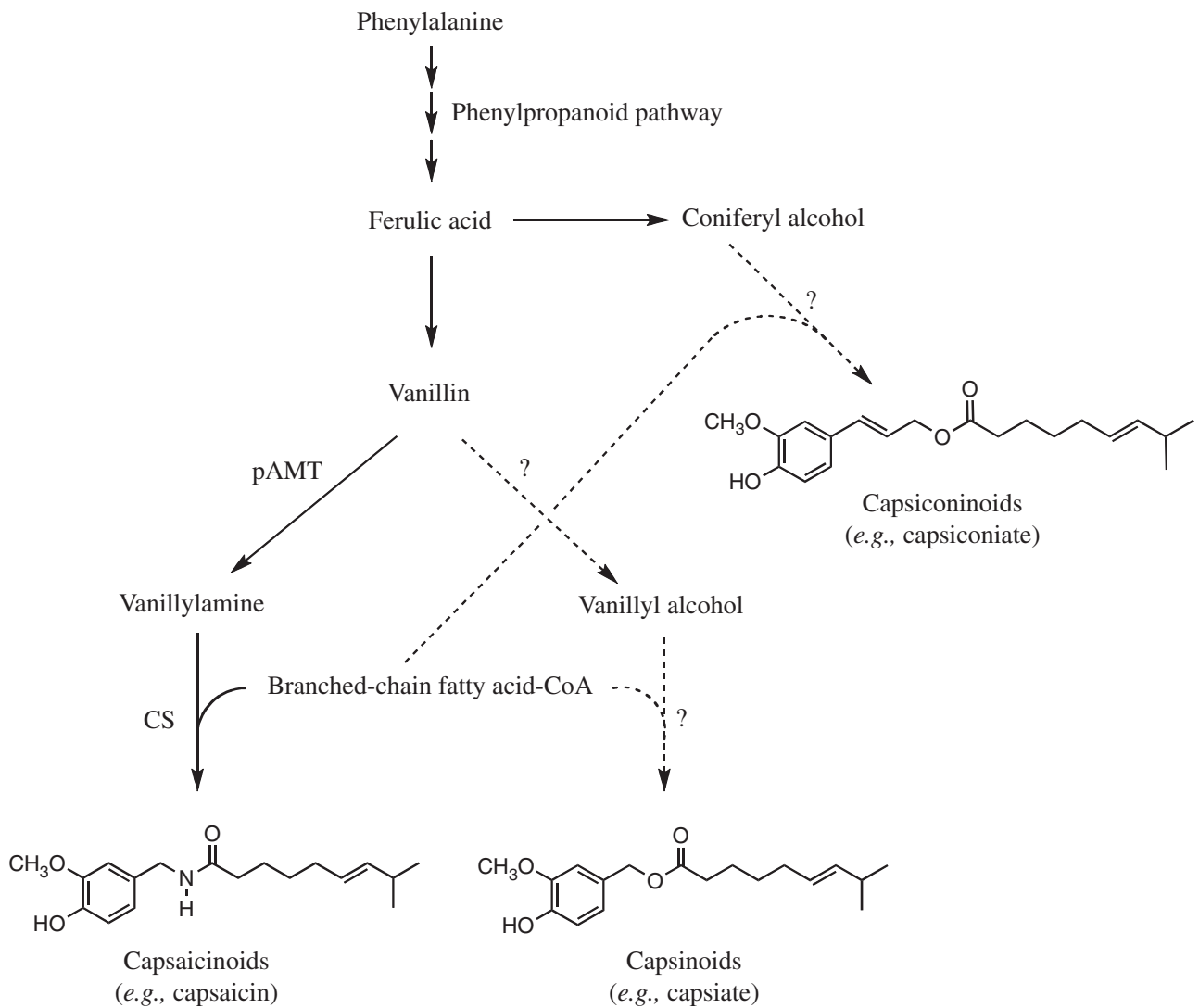

Fig. 1. Proposed Biosynthetic Pathway for Capsaicinoids, Capsinoids, and Capsiconinoids in Capsicum Plants. pAMT, putative aminotransferase; CS, capsaicin synthase.

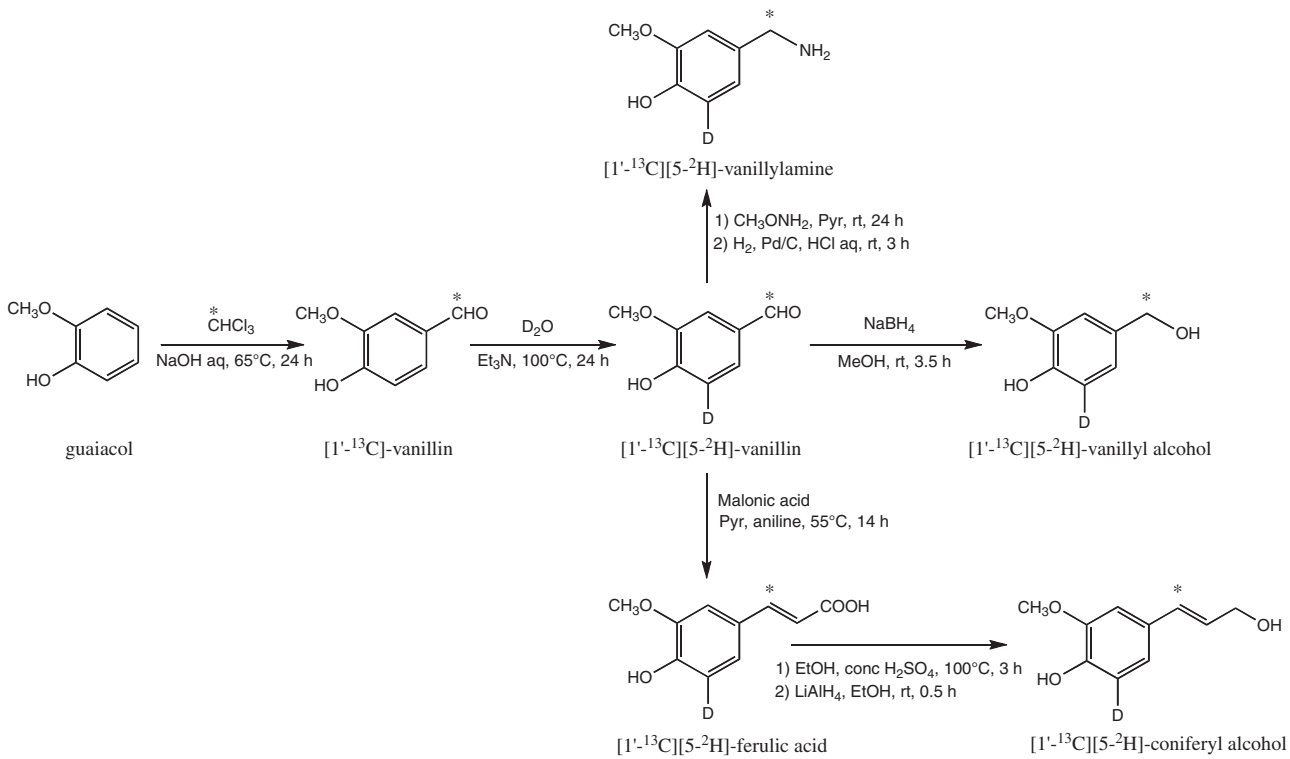

Fig. 2. Synthetic Scheme for the Stable Isotope-Labeled Precursors

$*,{ }^{13} \mathrm{C} ; \mathrm{D},{ }^{2} \mathrm{H}$.

atmospheric pressure chemical ionization-mass spectrometric (APCI-MS) spectrum $^{9)}$ showed a protonated molecular ion peak at $m / z 154$.

$\left[1^{\prime}-{ }^{13} \mathrm{C}\right]\left[5-{ }^{2} \mathrm{H}\right]-$ Vanillin was prepared according to the method of Krings et al. ${ }^{10)}$ with a slight modification. Briefly, a mixture of $53.7 \mathrm{mg}$ of $\left[1^{\prime}{ }^{13} \mathrm{C}\right]$-vanillin $(0.37 \mathrm{mmol}), 290 \mu \mathrm{L}$ of deuterium oxide $(14.5 \mathrm{mmol})$, and $52 \mu \mathrm{L}$ of triethylamine was heated at $100^{\circ} \mathrm{C}$ for $24 \mathrm{~h}$ under nitrogen gas. The ethyl acetate extracted from the reaction mixture gave $55.2 \mathrm{mg}(0.36 \mathrm{mmol})$ of [1'- $\left.{ }^{13} \mathrm{C}\right]\left[5-{ }^{2} \mathrm{H}\right]$-vanillin. The ${ }^{1} \mathrm{H}-\mathrm{NMR}$ spectrum of the compound showed signal attenuation at $7.04 \mathrm{ppm}$, this being assigned to the 5-position of the benzene ring of vanillin. The rate of substitution of a proton with deuterium at the 5-position of vanillin was calculated as $89 \%$ from the area of the attenuated proton signal. The positive APCI-MS spectrum showed a protonated molecular ion peak at $m / z 155$.

$\left[1^{\prime}-{ }^{13} \mathrm{C}\right]\left[5-{ }^{2} \mathrm{H}\right]-$ Vanillylamine was prepared from $\left[1^{\prime}-\right.$ $\left.{ }^{13} \mathrm{C}\right]\left[5-{ }^{2} \mathrm{H}\right]$-vanillin via an oxime according to the 
method of Gannett et al. ${ }^{11)}$ with a slight modification. Briefly, a mixture of $100.8 \mathrm{mg}$ of $\left[1^{\prime}{ }^{13} \mathrm{C}\right]\left[5-{ }^{2} \mathrm{H}\right]$-vanillin $(0.65 \mathrm{mmol}), 60.0 \mathrm{mg}$ of methoxyamine hydrochloride $(0.78 \mathrm{mmol})$, and $18 \mathrm{~mL}$ of dry pyridine was agitated for $24 \mathrm{~h}$ at room temperature. The reaction mixture was then subjected to rotary evaporation in vacuo to eliminate pyridine. $\mathrm{CHCl}_{3}$ extracted from the residue gave $109.5 \mathrm{mg}$ of $\left[1^{\prime}-{ }^{13} \mathrm{C}\right]\left[5-{ }^{2} \mathrm{H}\right]-4$-hydroxy-3-methoxybenzaldehyde $O$-methyloxime $(0.60 \mathrm{mmol}, 92 \%$ yield $)$. A mixture of $20.2 \mathrm{mg}$ of the oxime $(0.11 \mathrm{mmol}), 42 \mathrm{mg}$ of palladium carbon, and $79 \mathrm{~mL}$ of $12 \mathrm{M} \mathrm{HCl}$ was agitated at room temperature for $3 \mathrm{~h}$ in $150 \mathrm{~cm}^{3}$ of hydrogen gas. The reaction mixture was passed through Celite to remove the palladium carbon, and was then subjected to rotary evaporation in vacuo to afford $21.7 \mathrm{mg}$ of [ $1^{\prime}$ $\left.{ }^{13} \mathrm{C}\right]\left[5-{ }^{2} \mathrm{H}\right]$-vanillylamine $(51 \%$ purity by HPLC, $60 \%$ total yield from $\left[1^{\prime}-{ }^{13} \mathrm{C}\right]\left[5-{ }^{2} \mathrm{H}\right]$-vanillin). The ${ }^{1} \mathrm{H}-\mathrm{NMR}$ spectrum showed a set of doublet signals of 2 protons coupled with $142 \mathrm{~Hz}$ at $4.01 \mathrm{ppm}$, indicating the presence of a labeled methylene group together with amine and phenyl groups. Labeled methylene was observed as an extremely intense signal at $44 \mathrm{ppm}$ in the ${ }^{13} \mathrm{C}-\mathrm{NMR}$ spectrum. The other signals in these spectra were similar to those of standard vanillylamine, except for the signal indicating deficiency at the 5-position in the labeled compound in its ${ }^{1} \mathrm{H}-\mathrm{NMR}$ spectrum. The positive APCIMS data for standard vanillylamine shows a typical fragment ion peak predominantly at $m / z 137$ caused by the elimination of an amine group. Labeled vanillylamine showed a fragment ion peak at $m / z \quad 139$, indicating that 2 labels remained in the fragment.

$\left[1^{\prime}-{ }^{13} \mathrm{C}\right]\left[5-{ }^{2} \mathrm{H}\right]-$ Vanillyl alcohol was prepared by $\mathrm{NaBH}_{4}$ reduction of $\left[1^{\prime}-{ }^{13} \mathrm{C}\right]\left[5-{ }^{2} \mathrm{H}\right]$-vanillin. We added $12 \mathrm{mg}$ of $\mathrm{NaBH}_{4}(0.32 \mathrm{mmol})$ to $2.4 \mathrm{~mL}$ of an $\mathrm{MeOH}$ solution containing $23.9 \mathrm{mg}$ of $\left[1^{\prime}-{ }^{13} \mathrm{C}\right]\left[5-{ }^{2} \mathrm{H}\right]$-vanillin $(0.16 \mathrm{mmol})$, and placed the mixture at room temperature for $3.5 \mathrm{~h}$. Excess water was added to the reaction mixture, and subsequent ethyl acetate extraction gave $24.8 \mathrm{mg}$ of $\left[1^{\prime}-{ }^{13} \mathrm{C}\right]\left[5-{ }^{2} \mathrm{H}\right]$-vanillyl alcohol $(0.16 \mathrm{mmol})$. The ${ }^{1} \mathrm{H}-\mathrm{NMR}$ spectrum showed a set of doublet signals of 2 protons coupled with $144 \mathrm{~Hz}$ at $4.59 \mathrm{ppm}$, indicating the labeled methylene group together with hydroxy and phenyl groups. The other signals in these spectra were similar to those of standard vanillyl alcohol, except for the signal indicating a deficiency at the 5-position in the labeled compound in its ${ }^{1} \mathrm{H}-\mathrm{NMR}$ spectrum. The positive APCI-MS data for the labeled compound showed a typical fragment ion peak predominantly at $\mathrm{m} / \mathrm{z} 138$ caused by elimination of the aliphatic hydroxy group of vanillyl alcohol.

$\left[1^{\prime}-13 \mathrm{C}\right]\left[5-{ }^{2} \mathrm{H}\right]-$ Ferulic acid was prepared from $\left[1^{\prime}-\right.$ $\left.{ }^{13} \mathrm{C}\right]\left[5-{ }^{2} \mathrm{H}\right]$-vanillin according to the method of Krings et al. ${ }^{10)}$ with a slight modification. A mixture of $23.0 \mathrm{mg}$ of $\left[1^{\prime}-{ }^{13} \mathrm{C}\right]\left[5-{ }^{2} \mathrm{H}\right]$-vanillin $(0.15 \mathrm{mmol}), \quad 31.0 \mathrm{mg}$ of malonic acid $(0.30 \mathrm{mmol}), 46 \mu \mathrm{L}$ of pyridine, and $5 \mu \mathrm{L}$ of aniline was heated at $55^{\circ} \mathrm{C}$ for $14 \mathrm{~h}$. We then added $200 \mu \mathrm{L}$ of $5 \mathrm{M} \mathrm{HCl}$ and $30 \mathrm{~mL}$ of water to the reaction mixture. Subsequent ethyl acetate extraction gave $24.0 \mathrm{mg}$ of $\left[1^{\prime}-{ }^{13} \mathrm{C}\right]\left[5-{ }^{2} \mathrm{H}\right]$-ferulic acid $(0.12 \mathrm{mmol}$, $80.0 \%$ yield). The ${ }^{13} \mathrm{C}$-NMR spectrum of the compound showed an extremely intense signal at $148 \mathrm{ppm}$ indicating a $\mathrm{sp}^{2}{ }^{13} \mathrm{C}$ isotope of carbon. The ${ }^{1} \mathrm{H}-\mathrm{NMR}$ spectrum showed a set of double-doublet signals coupled with 155 and $16 \mathrm{~Hz}$ at $7.59 \mathrm{ppm}$, indicating a conjugated olefinic proton attached to the ${ }^{13} \mathrm{C}$ isotope with trans configuration. The other signals in these spectra were similar to those of standard ferulic acid, except for the signal corresponding to a deficiency at the 5-position in the labeled compound in its ${ }^{1} \mathrm{H}-\mathrm{NMR}$ spectrum. The negative APCI-MS data showed a deprotonated molecular ion peak at $m / z 195$.

$\left[1^{\prime}-{ }^{13} \mathrm{C}\right]\left[5-{ }^{2} \mathrm{H}\right]$-Coniferyl alcohol was prepared from $\left[1^{\prime}-{ }^{13} \mathrm{C}\right]\left[5-{ }^{2} \mathrm{H}\right]$-ferulic acid via its ethyl ester according to the method of Quideau and Ralph ${ }^{12)}$ with a slight modification. A mixture of $81.0 \mathrm{mg}$ of $\left[1^{\prime}{ }^{13} \mathrm{C}\right]\left[5-{ }^{2} \mathrm{H}\right]-$ ferulic acid $(0.41 \mathrm{mmol}), 800 \mu \mathrm{L}$ of conc. $\mathrm{HCl}$, and $10 \mathrm{~mL}$ of ethyl alcohol was heated for $3 \mathrm{~h}$ at $100^{\circ} \mathrm{C}$. After evaporating the reacted mixture, the resulting residue gave a corresponding amount of an ethyl ester. This ethyl ester was dissolved in $5 \mathrm{~mL}$ of dehydrated diethyl ether, and $137 \mathrm{mg}$ of $\mathrm{LiAlH}_{4}$ was then added to the solution. The mixture was allowed to remain at room temperature for $30 \mathrm{~min}$, and then the catalyst was removed by filtration. The ethyl acetate extract from the residue was purified by ODS column chromatography to afford $22 \mathrm{mg}$ of $\left[1^{\prime}-{ }^{13} \mathrm{C}\right]\left[5-{ }^{2} \mathrm{H}\right]$-coniferyl alcohol $(0.12 \mathrm{mmol}, 29 \%$ yield $)$. The ${ }^{1} \mathrm{H}-\mathrm{NMR}$ spectrum showed a set of double-doublet signals coupled with 150 and $16 \mathrm{~Hz}$ at $6.53 \mathrm{ppm}$, indicating a shift of the olefinic proton at the $1^{\prime}$-position because of the reduction from carboxylic acid to an alcohol. The other signals in the spectrum were similar to those of standard coniferyl alcohol, except for the signal indicating a deficiency at the 5-position in the labeled compound. The positive APCI-MS data showed a dehydroxy molecular ion peak at $m / z 165$, this being 2 masses larger than that of standard coniferyl alcohol.

A preliminary experiment was carried out for measuring the capsaicin synthase (CS) activity in a crude enzyme solution extracted from the Capsicum pepper fruits according to the method of Fujiwake et al. ${ }^{13)}$ with a slight modification. Conversion of the labeled vanillylamine into a labeled vanillyl octanamide, a model analog of capsaicin, was measured by an LC-MS/MS system (LC: Nanospace SI-1, Shiseido, Tokyo, Japan; MS/MS: API 2000, Applied Biosystems, Carlsbad, CA, USA). The placenta and dissepiment $(1.4 \mathrm{~g})$ were dissociated from 3 pods of fresh fruits of Habanero (Capsicum chinense) and were ground at $4{ }^{\circ} \mathrm{C}$ with $3 \mathrm{~mL}$ of $50 \mathrm{~mm}$ Tris- $\mathrm{HCl}$ ( $\mathrm{pH} 8.0$ ) containing $1 \%$ Triton $\mathrm{X}-100$. After centrifuging at $2000 \mathrm{~g}$ and $4{ }^{\circ} \mathrm{C}$ for $30 \mathrm{~min}$, the supernatant was used as the crude enzyme solution $(8.6 \mathrm{mg} / \mathrm{mL}$ in protein content). We incubated $100 \mu \mathrm{L}$ of a $50 \mathrm{~mm}$ Tris- $\mathrm{HCl}(\mathrm{pH} 8.0)$ solution containing $2 \mathrm{~mm}$ $\left[1^{\prime}-{ }^{13} \mathrm{C}\right]\left[5-{ }^{2} \mathrm{H}\right]$-vanillylamine, $1 \mathrm{~mm}$ octanoyl-CoA (Sigma), and $10 \mu \mathrm{L}$ of the enzyme solution at $37^{\circ} \mathrm{C}$ for $1 \mathrm{~h}$. The reaction was terminated by adding $6 \mathrm{M} \mathrm{HCl}$ to the mixture. The ethyl acetate extract from the mixture was dried and then dissolved in $\mathrm{MeOH}$ containing $0.1 \%$ acetic acid for an LC-MS/MS analysis. The LC-MS/MS conditions for measuring vanillyl octanamide were as follows: LC column, a reversed-phase Unison UK-C18 silica gel column ( $2 \mathrm{~mm}$ i.d. $\times 150 \mathrm{~mm}$ (Imtakt Co., Kyoto, Japan)); column temperature, $40{ }^{\circ} \mathrm{C}$; solvent, 70 $100 \% \mathrm{MeOH}$ containing $0.1 \%$ acetic acid (0-10 min); flow rate, $0.2 \mathrm{~mL} / \mathrm{min}$; injection volume, $5 \mu \mathrm{L}$; MS $/ \mathrm{MS}$ ion source, ESI; polarity, positive; detection mode, multiple reaction monitoring (MRM); detected ions, 
precursor/product, 280/137 for the natural predominant isotope of vanillyl octanamide [M] and 282/139 for the labeled one $[\mathrm{M}+2]$. The optimum parameters for detecting vanillyl octanamide were automatically tuned by using an authentic sample with Analyst software (Applied Biosystems). The ions of vanillyl octanamide were observed in the mass chromatogram at $4.38 \mathrm{~min}$.

The enzyme solution from native Habanero contained a trace of vanillyl octanamide (the naturally predominant isotope [M], $3.9 \mathrm{nmol} / \mathrm{mg}$ of protein). A negligible amount of the native $[\mathrm{M}+2]$ isotope $(50 \mathrm{pmol} / \mathrm{mg}$ of protein) was observed as $1.2 \%$ of the abundance ratio that coincides with the calculated abundance ratio of the isotope $(1.3 \%)$. Incubating the enzyme solution with labeled vanillylamine and octanoyl-CoA substantially increased the amount of the $[\mathrm{M}+2]$ isotope of vanillyl octanamide to $370 \mathrm{pmol} / \mathrm{mg}$ of protein, and its abundance ratio was $8.8 \%$. No marked increase in the $[\mathrm{M}+2]$ isotope was apparent in the absence of the enzyme or when using its boiled solution.

We synthesized in this study stable isotope-labeled precursors for capsaicinoid, capsinoid, and capsiconinoid biosyntheses and showed that the precursors could be useful tools for biosynthetic studies. Further investigations are in progress using the labeled precursors for information on the flow and properties of enzymes involved in the biosyntheses.

\section{Acknowledgments}

This work was supported by Grant-Aid for Scientific Research (C, 19580125) from JPSP (Japan) and by the Global Center of Excellence (COE) program from MEXT (Japan).

\section{References and Notes}

1) Suzuki T and Iwai K, "Alkaloids" Vol. 23, ed. Brossi A, Academic Press, New York, pp. 227-299 (1984).

2) del Rosario Abraham-Juárez M, del Carmen Rocha-Granados M, López MG, Rivera-Bustamante FR, and Ochoa-Alejo N, Planta, 227, 681-695 (2008).

3) Stewart CJr, Kang BC, Liu K, Mazourek M, Moore SL, Yoo EY, Kim BD, Paran I, and Jahn MM, Plant J., 42, 675-688 (2005).

4) Singh S, Jarret R, Russo V, Majetich G, Shimkus J, Bushway R, and Perkins B, J. Agric. Food Chem., 57, 3452-3457 (2009).

5) Sutoh K, Kobata K, Yazawa S, and Watanabe T, Biosci. Biotechnol. Biochem., 70, 1513-1516 (2006).

6) Tanaka Y, Hosokawa M, Otsu K, Watanabe T, and Yazawa S, J. Agric. Food Chem., 57, 5407-5412 (2009).

7) Ohara M and Fukuda J, Pharmazie, 33, 467 (1978).

8) ${ }^{1} \mathrm{H}$ - and ${ }^{13} \mathrm{C}$-NMR spectra (tetramethylsilane was used as the internal standard) of all the compounds were recorded on a JEOL $\alpha-400$ instrument (JEOL, Tokyo, Japan) at 399.65 and $100.40 \mathrm{MHz}$, respectively.

9) APCI-MS analyses of all the compounds were performed with the API2000 system (Applied Biosystems, Carlsbad, CA, USA). Thirty $\mu \mathrm{L} / \mathrm{min}$ of $10 \mu \mathrm{M}$ compound was infused into the system with $200 \mu \mathrm{L} / \mathrm{min}$ of $\mathrm{MeOH}$ containing $0.1 \%$ acetic acid. The ion source was APCI and detection polarity was positive. The optimum parameters for the detection of each compound were tuned automatically by the Analyst software (Applied Biosystems).

10) Krings U, Pilawa S, Theobald C, and Berger RG, J. Biotechnol., 85, 305-314 (2001)

11) Gannett PM, Nagel DL, Reilly PJ, Lawson T, Sharpe J, and Toth B, J. Org. Chem., 53, 1064-1071 (1988).

12) Quideau S and Ralph J, J. Agric. Food Chem., 40, 1108-1110 (1992).

13) Fujiwake H, Suzuki T, Oka S, and Iwai K, Agric. Biol. Chem., 44, 2907-2912 (1980). 